\title{
PARTISIPASI MASYARAKAT DALAM PENGELOLAAN DAYA TARIK WISATA TIRTHA EMPUL DI DESA MANUKAYA LET, KECAMATAN TAMPAKSIRING, KABUPATEN GIANYAR
}

\author{
Ni Gusti Ayu Kartika 1 \\ ${ }^{I}$ Universitas Hindu Negeri I Gusti Bagus Sugriwa Denpasar:
}

\section{ABSTRAK}

Era otonomi daerah sebagai implikasi dari berlakunya UU No. 32 tahun 2004, memberikan peluang bagi setiap Pemerintah Kabupaten/Kota untuk merencanakan dan mengelola pembangunan daerahnya sendiri, serta tuntutan bagi partisipasi aktif masyarakat dalam proses pembangunan dari perencanaan, pelaksanaan, monitoring dan evaluasi. Masyarakat sebagai komponen utama dalam pembangunan pariwisata berbasis masyarakat mempunyai peranan penting dalam menunjang pembangunan pariwisata daerah yang ditujukan untuk mengembangkan potensi lokal yang bersumber dari alam, sosial budaya ataupun ekonomi masyarakat. UU No 9 Tahun 1990 tentang Kepariwisataan menyatakan bahwa masyarakat memiliki kesempatan yang sama dan seluas-luasnya untuk berperan serta dalam penyelenggaraan kepariwisataan. Peran serta masyarakat dalam memelihara sumber daya alam dan budaya yang dimiliki merupakan andil yang besar dan berpotensi menjadi daya tarik wisata. Masyarakat lokal Desa Adat Manukaya Let Kecamatan Tampaksiring, Kabupaten Gianyar memegang peranan penting dalam perencanaan dan pengembangan wisata pusaka di Pura Tirta Empul. keterlibatan masyarakat lokal dalam kegiatan pariwisata di Pura Tirta Empul tidak memberikan manfaat ekonomi langsung kepada seluruh masyarakat lokal yang terlibat dalam operasional pariwisata untuk menopang kehidupan keluarganya karena masih tetap menjalankan profesinya masing-masing sebagai petani, peternak, pedagang dan karyawan atau pegawai lainnya untuk memenuhi kebutuhan sehari-hari.

Kata Kunci: Sosial budaya; Masyarakat; Tirta Empul

\begin{abstract}
The era of regional autonomy as an implication of the enactment of Law no. 32 of 2004, provides opportunities for each Regency/City Government to plan and manage their own regional development, as well as demands for active community participation in the development process from planning, implementation, monitoring and evaluation. The community as the main component in the development of community-based tourism has an important role in supporting the development of regional tourism which is aimed at developing local potential that comes from nature, socio-culture or the community's economy. Law No. 9 of 1990 concerning Tourism states that the community has the same and widest opportunity to participate in the implementation of tourism. Community participation in maintaining the natural and cultural resources owned is a big contribution and has the potential to become a tourist attraction. The local community of Manukaya Let Traditional Village, Tampaksiring District, Gianyar Regency plays an important role in planning and
\end{abstract}


developing heritage tourism at Tirta Empul Temple. the involvement of local communities in tourism activities at Tirta Empul Temple does not provide direct economic benefits to all local communities involved in tourism operations to support their families' lives because they are still carrying out their respective professions as farmers, breeders, traders and employees or other employees to meet their needs. daily..

\section{Keywords : Socio-cultural; Public; Tirta Empul}

\section{PENDAHULUAN}

Secara administratif Pura Tirtha Empul terletak di Desa Manukaya Let, Kecamatan Tampaksiring, Kabupaten Gianyar, Provinsi Bali. Pura ini berjarak kira-kira 50 kilometer dari pusat Kota Denpasar atau sekitar 90 menit ditempuh dengan kendaraan pribadi; atau kurang lebih 75 kilometer dari Bandar Udara Internasional Ngurah Rai yang membutuhkan waktu sekitar dua jam untuk mencapai Pura ini.

Selain sebagai tempat suci Agama Hindu di Bali, Pura Tirtha Empul juga telah ditetapkan sebagai salah satu kawasan situs Arkeologi di Bali oleh Balai Pelestarian Peninggalan Purbakala Bali, Dinas Kebudayaan Provinsi Bali yang dilindungi dengan Undang-Undang Nomor 5 Tahun 1992. Di dalam Pura ini tersimpan beberapa peninggalan bersejarah berupa artefak lingga sebagai representasi laki-laki dan yoni melambangkan perempuan sebagai simbol dari rwa bineda (dua hal yang berbeda) yang terletak di Madya Mandala - bagian halaman tengah Pura . Dalam kaitannya dengan warisan budaya dunia, Pura Tirtha Empul merupakan bagian hulu dari kawasan Tukad Pakerisan yang mencakup Pura Tirtha Empul, Pura Mangening dan Pura Gunung Kawi yang letaknya berurutan dari hulu ke hilir di sepanjang aliran Sungai Pakerisan.

Melihat dua fungsi ini, Pura Tirtha Empul tidak hanya menawarkan suasana religi dan mendapatkan pengalaman spiritual yang memungkinkan pengunjung berlatar belakang agama Hindu untuk bersembahyang dan berdoa sehingga merasa lebih dekat dengan Tuhan, tetapi juga memberikan kesempatan kepada pengunjung non Hindu (tourist) untuk menyaksikan dan mengikuti

\section{GB Sugriwa Denpasar. All Right Reserved} kegiatan ritual secara langsung di Pura yang dipaketkan dalam "businespariwisata". Dengan kata lain, bahwa di Pura ini telah terjadi perubahan dan penambahan fungsi utama Pura yaitu sebagai tempat suci yang bersifat sacred; dan sekarang ini bertambah fungsi sebagai penghasil pendapatan yang bersifat secular dan transaksional yang diperoleh dari penjualan tiket masuk ke Pura yang dikenakan kepada setiap wisatawan yang berkunjung yang selanjutnya dana tersebut dikembalikan ke Pura untuk digunakan sebagai dana pelestarian Pura serta pendapatan daerah pemerintah daerah setempat. Tujuan Dari Penelitian ini adalah Mengetahui Tipologi Partisipasi Masyarakat Dalam Pengelolaan Daya Tarik Wisata Tirtha Empul Di Desa Manukaya Let, Kecamatan Tampaksiring, Kabupaten Gianyar.

\section{HASIL DAN PEMBAHASAN}

\subsection{Sejarah Pura Tirtha Empul}

Pura Tirtha Empul merupakan salah satu Pura tertua di Bali yang didirikan jauh sebelum Pura-Pura lain berdiri di seluruh wilayah Bali yang dapat dilihat secara jelas dari jenis bangunan-bangunan suci atau pelinggih yang ada di bagian paling suci Pura (utama mandala). Berdasarkan beberapa peninggalan sejarah yang ditemukan di Pura ini yang merupakan bagian terpenting dari sejarah Pura Tirtha Empul dan penyebaran agama Hindu di Bali.

Kedatangan orang-orang suci yang menyebarkan agama Hindu di Bali dapat dilihat dari jenis bangunan-bangunan suci yang dibangun pada masa kedatangannya. Pendeta Hindu Mpu Kuturan misalnya yang datang ke Bali sekitatr abad ke-11 
memperkenalkan tentang Meru sebagai tempat pemujaan Ida Sang Hyang Widhi Wasa-Tuhan Yang Maha Esa dalam perwujudan Beliau sebagai tiga dewa yang disebut sebagai tri murti yang terdiri atas Brahma sebagai pencipta, Wisnu sebagai pemelihara dan Siwa sebagai pelebur (Dwijendra 2009). Sehingga, tempat-tempat yang menjadi persinggahan beliau selama dalam perjalanan sucinya di Pulau Bali dibangun Pura yang berisi bangunan Meru sebagai tempat pemujaan utamanya.

Pendeta Hindu lainnya, Dang Hyang Nirartha datang ke Bali sekitar ke-15 dan memperkenalkan bangunan suci padmasana yang merupakan tempat pemujaan Tuhan Yang Maha Esa dalam perwujudan beliau sebagai Siwa yang merupakan manifestasi dari Siwa, Sadha Siwa dan Parama Siwa (Dwijendra 2009; Nurkancana 2009). Di era kedatangan pendeta Hindu inilah banyak dikembangkan bangunan-bangunan suci berbentuk padmasana di Pura -Pura di seluruh pelosok Bali baik pura keluarga, pura umum, pura territorial (pura desa, pura puseh, pura dalem) maupun pura swagina (pura yang pemujanya satu profesi).

Kedua jenis bangunan suci ini "Meru dan Padmasana" merupakan ciri khas dari Pura Hindu di Bali yang dibangun pada saat kedatangan kedua pendeta tersebut. Sampai sekarang ini masih tetap dipertahankan kedua jenis bangunan suci tersebut, dan keberadaannya oleh umat Hindu di Bali sebagai simbol Tuhan dan media bagi manusia untuk mendekatkan diri dengan sang pencipta yang disebut dengan berbagai nama sebagaimana dijelaskan di atas.

Berbagi kesan tentang suatu objek wisata, tidak hanya berfungsi untuk memperkenalkan tempat wisata tersebut kepada khalayak umum, tetapi juga bisa menarik minat orang yang membaca pengalaman baik tersebut untuk mengunjungi dan menikmati objek wisata tersebut.

Keunikan ritual Malebur di Pura Tirtha Empul tidak hanya menarik wisatawan untuk melihat (gazing) kegiatan religi yang dilakukan oleh umat Hindu saja, namun juga membangkitkan keinginan wisatawan untuk ikut mencoba atau berpartisipasi (enganging) dalam kegiatan ritual tersebut. Dengan partisipasi ini, wisatawan bisa merasakan langsung kasiat dari air suci di Pura Tirtha Empul yaitu membersihkan diri secara fisik (raga) dan juga membersihkan pikiran (jiwa) sehingga setelah melakukan permandian suci tersebut tercipta rasa bersih lahir dan bathin. Hal yang lebih penting dari partisipasi wisatawan dalam kegiatan ritual tersebut adalah timbulnya kesadaran untuk menghormati nilai-nilai budaya masyarakat lokal yang telah dijunjung tinggi dari generasi ke generasi. Sehingga, partisipasi wisatawan dalam kegiatan budaya lokal yang telah dipelajari dan diterapkan oleh generasi terkini dari generasi sebelumnya menumbuhkan sense (rasa) cinta terhadap budaya lokal (Katan 2012).

\subsection{Kegiatan Wisata Pura di Pura Tirtha Empul: Pengelola dan Urutan Kegiatan}

Keunikan budaya dan keindahan arsitektur Pura serta beragam ritual yang dilakukan umat Hindu di Pura Tirtha Empul yang tidak pernah terhenti dari pagi hingga malam telah menjadi daya tarik tersendiri bagi wisatawan domestic maupun internasional untuk mengunjungi Pura ini, selain dari letaknya yang strategis berada di jalur atau rute wisata antara Ubud yang merupakan pusat atraksi budaya di Kabupaten Gianyar dan Kintamani yang merupakan tempat dimana wisatawan bisa melihat pemandangan indah Danau Batur dan Gunung Batur di wilaah Kabupaten Bangli (Subadra 2015). Hal ini sesuai dengan pendapat Richards (2005) bahwa budaya merupakan salah satu faktor penarik (pull factor) dan factor pendorong (push factor) bagi wisatawan untuk mengunjungi suatu destinasi wisata.

Di satu sisi, wisatawan tertarik untuk mengunjungi Pura Tirtha Empul karena objek dan aktivitas budaya yang tersedia di Pura tersebut sangat menarik dan unik yang berbeda dengan kegiatan ritual di Pura -Pura 
lainnya di Bali. Di sisi lain, karena keunikan budaya tersebut wisatawan juga terdorong untuk datang dan berkunjung serta mempelajari tentang budaya masyarakat Hindu Bali yang diterapkan di Pura Tirtha Empul secara lebih mendalam agar bisa memperoleh pemahaman secara komprehensif.

Seiring dengan tumbuh dan berkembangnya pariwisata di Bali yang diperkirakan sejak tahun 1920an, Pura ini juga turut dijadikan sebagai objek atau daya tarik untuk dilihat (object of the gaze) bagi wisatawan atau sebagai atraksi (attraction) yang menarik wisatawan untuk mengunjungi Pura ini yang merupakan salah satu indicator dari suatu destinasi wisata (Ariya dkk. 2017). Subadra (2015) mencatat bahwa Pura Tirtha Empul telah mulai dikunjungi oleh wisatawan sejak tahun 1974 dan ditetapkan sebagai salah satu objek dan daya tarik wisata di Kabupaten Gianyar berdasarkan Surat Keputusan Bupati Nomor 402 of 2008. Dengan penetapan ini, Pura Tirtha Empul secara resmi terbuka untuk umum dan bisa dikunjungi oleh wisatawan yang tertarik dengan atraksi wisata berbasis Pura dengan tetap mematuhi setiap peraturan yang berlaku di Pura ini.

Rangkaian kegiatan tour di kawasan Pura Tirtha Empul dimulai dari pembelian tiket masuk di konter yang letaknya di halaman parkir mobil dimana para wisatawan turun dari mobilnya. Kemudian wisatawan berjalan menuju ke Pura melalui pos pemeriksaan tiket dan dilanjutkan menuju konter sarung dan selendang yang letaknya sebelum gerbang masuk di halaman Nista Mandala. Semua wisatawan yang masuk ke dalam Pura Tirtha Empul wajib menggunakan sarung dan selendang yang berfungsi untuk menutupi aurat dan menghormati umat Hindu yang sedang melaksanakan kegiatan ritual di Pura .

Wisatawan yang sudah memakai pakaian adat Bali selanjutnya memasuki halaman Nista Mandala dimana disambut dengan keindahan candi bentar menuju ke permandian suci dan candi kurang dengan latar belakang pemandangan Istana Presiden Tampaksiring. Pada halaman inilah wisatawan biasanya mulai mengambil fotofoto bagian luar arsitektur Pura dan foto umat Hindu yang lalu lalang menjinjing sesajen menuju halaman Pura untuk bersembahyang dank e luar dari Pura setelah melakukan persembahyangan.

Selanjutnya, wisatawan memasuki komplek permandian suci yang termasuk dalam areal Madya Mandala melalui candi bentar. Pada halaman ini, wisawatan bisa melihat atau menyaksikan kegiatan ritual Hindu yang dilakukan oleh orang-orang Bali sebagai bagian dari budaya hariannya (daily culture) secara langsung atau dengan kepala dan matanya sendiri, seperti persembahan sesajen di meja yang letaknya di depan permandian suci, persembahyangan umat Hindu sebelum memulai ritual permandian, dan ritual mandi suci yang dilakukan pada komplek permandian 13 pancuran yang kemudian dilanjutkan ke komplek permandian 8 pancuran yang letaknya bersebelahan dan hanya disekat dengan tembok sekat pembatas.

Kegiatan budaya yang unik dan langsung dilakukan oleh umat Hindu di Pura Tirtha Empul yang merupakan bagian yang tidak terpisah dari kepercayaannya kepada Tuhan dan aktivitas budayanya sehari-hari inilah yang Subadra (2015) sebut sebagai atraksi budaya asli (authentic cultural attraction). Artinya, bahwa aktivitas budaya berbasis Hindu yang dipertunjukkan untuk pariwisata di Pura Tirtha Empul tidak dengan sengaja dibuat oleh pengelola Pura tersebut untuk kepentingan pariwisata, misalnya umat Hindu yang melakukan ritual permandian suci sebagai aktor dari atraksi wisata budaya tidak dibayar untuk melakukan permandian disana. Kedatangan juga tidak diundang oleh pengelola Pura, sesajen yang dibawa dan dipersembahkan oleh umat Hindu tersebut tidak dibayar oleh pengelola Pura, dan pakaian serta perhiasan yang dipakainya juga bukan pesanan dari pengelola Pura untuk mengenakan kostum seperti itu; tetapi, itu semua murni atas inisiatif dan keinginan 
umat Hindu untuk datang ke Pura Tirtha Empul. Umat Hindu melakukan kegiatan permandian suci dan persembahyangan yang merupakan bagain penting dari kehidupan dan budayanya untuk menjaga keharmonisan hubungannya dengan Tuhan sebagai Sang Penciptaan atau dikenal dengan "Parahyangan" yang merupakan salah satu bagian dari konsep Tri Hita Karana.

Pengalaman mengikuti kegiatan budaya lokal di suatu destinasi akan menjadi kenangan wisata yang mengesankan dan tidak terlupakan dalam hidup wisatawan. Fakta ini wisatawan berkunjung ke suatu destinasi untuk mengamati dan mempelajari budaya lokal; namun lebih luas lagi, wisatawan memiliki kedekatan dengan masyarakat dan mengikuti kegiatan budaya (cultural engagement) yang dilakukan oleh masyarakat setempat (Subadra 2015).

Daya tarik wisata yang bisa dinikmati oleh wisatawan pada bagian Madya Mandala adalah arca peninggalan sejarah lingga-yoni dan pusat sumber mata air. Sesaat setelah melewati aling-aling (tembok yang terbentang di depan pintu masuk), wisatawan bisa melihat artefak kuno lingga-yoni ini. Kedua peninggalan ini sering dipakai oleh Pramuwisata dalam menjelaskan konsep rwa bhineda (dua hal yang berbeda) yang dipercayai oleh masyarakat Bali sebagai simbol keseimbangan alam semesta, misalnya tentang keberadaan jenis kelamin laki-laki dan perempuan, dan baik dan buruk karakteristik seseorang yang keduanya selalu ada secara bersamaan di suatu komunitas. Selain itu, dua rusa yang terletak di atas lingga-yoni juga dijadikan sebagai simbol kendaraan salah satu manifestasinya Tuhan yaitu Bhatara Siwa. Ini untuk memberikan visualisasi agar manusia lebih paham bahwa Tuhan bisa bergerak dan bahkan ada dimanamana.

Pada sumber mata air yang lebih dikenal sebagai Telaga Tirtha Suci yang mengaliri keempat komplek pancuran di hilirnya, wisatawan dapat mempelajari tentang pentingnya air dalam kehidupan manusia. Air jernih yang selalu muncul ke permukaan bumi dan bersumber dari Pura Tirtha Empul digunakan oleh masyarakat Bali untuk berbagai kepentingan. Fungsi utama air suci di Pura ini adalah sebagai air suci atau yang lazim disebut dengan "Tirtha" yang digunakan sebagai salah satu sarana persembahyangan bagi umat Hindu dan berfungsi untuk menyucikan jiwa dan raga manusia sebelum dan sesudah melakukan persembahyangan. Air suci yang tidak pernah berhenti mengepul dari bumi inilah yang dijadikan dasar penamaan Pura ini, yang mana Tirtha berarti "air suci", dan empul berarti "mengepul". Pura Tirtha Empul berarti Pura dimana terdapat air suci yang selalu ke luar dari permukaan bumi.

Fungsi lain dari air yang bersumber dari halaman Madya Mandala Pura Tirtha Empul adalah sebagai sumber mata air dari Sungai Pakerisan yang mengaliri persawahan di sepanjang sungai tersebut khususnya di wilayah Kecamatan Tampaksiring yang dibagi secara adil dengan sistem irigasi tradisional khas Bali bernama subak. Dalam konteks ini wisatawan diberikan penjelasan dan pemahaman tentang peran penting air dalam kehidupan dan kemakmuran masyarakat Bali khususnya bagi yang bergelut dalam bidang pertanian, sehingga semakin memperjelas bagaimana keterkaitan kepercayaan masyarakat Bali tentang manifestasi Tuhan "Bhatari Sri" sebagai dewi kemakmuran yang divisualisasikan dengan suburnya tanaman padi di kawasan persawahan yang merupakan sumber utama pangan masyarakat lokal dengan "Bhatara Indra" sebagai dewa air yang dipuja di Pura Tirtha Empul yang mengaliri sawah dan menyuburkan tanaman padinya.

Hal terpenting dari interpretasi sumber mata air ini adalah tentang sejarah Pura Tirtha Empul, yang sekarang ini dijadikan cerita rakyat dan masih dipercayai oleh masyarakat setempat. Dikisahkan pada jaman kerajaan Maya Denawa terjadi bencana kemanusiaan sakit masal atau yang di Bali dikenal dengan gerubug, kemudian datanglah Bhatara Indra dan menancapkan keris saktinya ke tanah pada halaman Pura ini dan 
kemudian ke luar air dari permukaan tanah dan selanjutnya dipercikkan kepada semua masyarakat yang sedang sakit dan akhirnya bisa sembuh kembali dan beraktivitas seperti biasanya sampai dengan generasi sekarang tanpa mara bahaya. Berdasarkan cerita inilah masyarakat lokal Desa Adat Manukaya Let sangat taat dalam berbakti dan mengabdikan dirinya kepada Bhatara Indra yang merupakan manifestasi Tuhan yang berstana di Pura Tirtha Empul.

Pada waktu tertentu, wisatawan bisa menyaksikan beberapa kegiatan ritual seperti: permohonan Tirtha suci, penyucian pratima (benda-benda sakral) dan meajar-ajar (ritual permakluman atas pelaksanaan kegiatan ritual besar yang sedang dilaksanakan di Pura masing-masing pada halaman madya mandala yang dilaksanakan oleh kelompok masyarakat atau desa adat yang berasal dari daerah lain di Pulau Bali. Kegiatan ini bisanya diiringi dengan gambelan Bali, sehingga wisatawan bisa melihat parade atau iring-iringan umat Hindu dengan menggunakan pakaian khas Bali membawa sesajen, benda-benda sakral yang turut serta dalam ritual tersebut; dan juga persembahyangan bersama yang dilaksanakan pada halaman madya mandala yang dipimpin oleh pendeta yang berasal dari daerahnya masing-masing.

Selain itu, ada keunikan lain yang dapat dijelaskan kepada wisatawan tentang pelaksanaan kegiatan ritual khususnya yang dipimpin oleh pendeta dari kalangan Brahmana pada halaman madya mandala Pura Tirtha Empul yang tidak ditemukan di Pura lainnya di Bali. Pendeta Hindu yang berlatar belakang keluarga Brahmana yang di Bali disebu dengan "Ida Pedanda" tidak pernah memimpin ritual keagamaan dan persembahyangan di utama mandala dan oleh karenanya hanya memimpin persembahyangan yang dilaksanakan di halaman Madya Mandala saja. Menurut pemangku (pendeta Pura ) yang sudah lama mengabdikan dirinya untuk melayani umat yang datang ke Pura Tirtha Empul, tidak adanya pendeta dari kalangan Brahmana yang memimpin persembahyangan di Utama Mandala Pura karena ketaatannya pada silsilah Pura yang mana keberadaan Pura Tirtha Empul jauh lebih lama dibandingkan dengan mulai munculnya Pendeta dari kalangan kasta Brahmana. Ini juga yang menjadi alasan yang tepat tentang tidak digunakannya sulinggih untuk memimpin ritualnya dalam upacara besar tahunan Pujawali (Subadra 2015).

Setelah menikmati dan mempelajari beberapa peninggalan bersejarah di halman madya mandala, wisatawan selanjutnya menuju Utama Mandala yang merupakan halaman Pura yang paling disucikan untuk melihat tempat pemujaan utama di Pura Tirtha Empul yang bernama Tepasana dimana umat Hindu mempersembahkan sesajennya pada saat melakukan persembahyangan di halaman ini. Secara fisik, Tepasana memiliki karakteristik yang berbeda dengan tempat-tempat pemujaan lainnya yang ada di Pura-Pura di Bali. Ini terlihat jelas dari struktur bangunannya yang tampak seperti bangunan belum selesai dimana diatasnya biasanya tumbuh rumput alang-alang; namun, inilah yang menjadi ciri khas palinggih (bangunan suci) utama dan dijadikan sebagai identitas Pura Tirtha Empul dan dikeramatkan sampai detik ini.

Selanjutnya, pada halaman utama mandala wisatawan juga bisa mempelajari tentang makna prosesi ritual dan persembahyangan yang dilakukan oleh umat Hindu di Pura Tirtha Empul. Wisatawan biasanya diberikan penjelasan tentang banten (sesajen) yang dipersembahkan dihadapan Tepasana, yang mana umat Hindu mempersembahkan sesajen yang umumnya berisi buah, kue, daging ayam atau telor, bunga, air dan api (dupa) sebagai simbol ucapan terima kasih atas berkah dan anugerah yang telah diberikan kepadanya. Setelah dipersembahkan, sesajen tersebut selanjutnya diambil kembali dan dinikmati oleh pembawanya di Wantilan yang terletak pada halaman nista mandala atau langsung dibawa pulang ke rumah masing-masing dan percaya bahwa semua isi sesajen tersebut 
telah diberkati oleh Tuhan dan akan memberikan kekuatan dalam hidupnya.

Wisatawan, juga akan mendapatkan penjelasan tentang rangkaian atau urutan persembahyangan yang disebut dengan panca sembah (lima persembahan kepada Tuhan) mencakup: persembahan kepada: (1) Tuhan yang memiliki karakteristik yang tidak berwujud guna mengosongkan pikiran dan selanjutnya memfokuskan pikiran kepada Tuhan Yang Maha Esa, (2) persembahan kepada Tuhan penguasa matahari yang memberikan penerangan dan energi dalam kehidupan di bumi ini, (3) persembahan kepada Bhatara Indra perwujudan Tuhan yang berstana di Pura Tirtha Empul, (4) persembahan kepada dewa-dewi untuk memohon anugerah, keselamatan, kesehatan dan kemakmuran, serta (5) persembahan kepada Tuhan sebagai ucapan terima kasih dan memohon kedamaian hati, di dunia dan akhirat. Penjelasan ini dapat memberikan pemahaman tentang budaya Bali dan kedinamisannya yang diimplementasikan langsung oleh umat Hindu di Pura dan sekaligus menjawab tanda tanya wisatawan kenapa kehidupan masyarakat lokal Bali sangat kental dengan kegiatan ritual keagamaan dan budaya.

Persembahyangan panca sembah diakhiri dengan pembagian Tirtha (air suci) yang dipercikan kepada semua umat yang telah melakukan persembahyangan guna menyucikan pikiran, perkataan dan perbuatan manusia; dan pembagian bija (beras suci) sebagai simbol dari kekuatan yang dianugerahkan oleh Tuhan kepada umatnya.

Terlebih lagi ketika berlangsungnya ritual tahunan Pujawali, wisatawan bisa menyaksikan beberapa pertunjukan tarian asli dan sakral seperti : tari baris, tari rejang dewa, tari rejang renteng dan tari topeng sidakarya pada halaman Utama Mandala. Namun, pertunjukan autentik ini belum banyak diketahui oleh wisatawan karena belum ada operator wisata yang membuat agenda kegiatan budaya tahunan dimana wisatawan dan calon wisatawan karena belum ada operator wisata yang membuat agenda kegiatan budaya tahunan dimana wisatawan bisa menyaksikan atraksi-atraksi budaya Bali yang asli dan dipersembahkan secara alami di Pura Hindu di Bali. Ini akan memberikan kesempatan kepada wisatawan untuk mempelajari tentang budaya Bali secara lebih mendalam yang sangat kental dan saling berkaitan antara seni, agama dan adat istiadat.

Keunikan budaya Bali yang dipraktikkan secara langsung oleh Umat Hindu di Pura Tirtha Empul tidak hanya memikat wisatawan asing dari kalangan biasa, namun juga wisatawan kelas elit seperti mantan Presiden Amerika Serikat Barack Hussein Obama. Setelah habis masa kepemimpinannya selama delapan (8) tahun sampai dengan Bulan Januari 2017, pada tanggal 23 Juni 2017 Presiden Amerika yang ke-44 ini berkunjung dan menikmati keindahan arsitektur Pura dan aktivitas buaya Bali yang sangat kental dengan suasana religi dalam rangkaian liburannya di Pulau Dewata selama sepekan. Kunjungan wisata ini bisa membantu mempromosikan Pura Tirtha Empul sebagai purification temple (Pura untuk penyucian diri) yang dijadikan sebagai identitas Pura tersebut secara lebih luas ke seluruh dunia karena kegiatan wisatanya diliput dan diberitakan oleh berbagai media masa dalam dan luar negeri.

Setelah menikmati atraksi wisata budaya berbasis Hindu pada halaman Utama Mandala, wisatawan meninggalkan hlaaman tersuci menuju halaman Madya Mandala dan mengembalikan sarung dan selendang pada pos dimana mengambil atau menggunakannya. Lalu, wisatawan diarahkan oleh petugas keamanan menuju ke komplek toko kerajinan seni (art shops) yang letaknya berdekatan sengan parker kendaraan dengan tujuan agar pada wisatawan bisa berbelanja beberapa souvenir untuk dibawa pulang sebagai kenangan atau dijadikan sebagai oleh-oleh buat keluarga, teman maupun teman sekerjanya sehingga wisatawan dapa mmeberikan kontribusi tiket masuk ke Pura . Para wisatawan disambut dengan ramah dan penuh senyum oleh para pemilik took 
kerajinan yang dimiliki oleh masyarakat lokal dan dikelola oleh Desa Adat Manukaya Let dan mempersilahkan wisatawan untuk melihat-lihat dan atau mencoba barang dagangannya serta menawarkan berbagai keunikan dan potongan harga agar wisatawan tertarik untuk membeli produk kesenian yang ditawarkan. Setelah berjalan mengelilingi komplek toko cindramata ini, wisatawan akhirnya sampai pada halaman parker para sopirnya telah siap dan siaga untuk menghantar wisatawan ke rute perjalanan wisata selanjutnya.

\subsection{Pentingnya Pramuwisata dalam Wisata Pura di Pura Tirtha Empul}

Keanekaragaman atraksi budaya berbasis Hindu yang bisa dinikmati oleh wisatawan domestik dan mancanegara di Pura Tirtha Empul memerlukan interpretasi agar wisatawan memiliki pemahaman yang mendalam (deep understanding) terhadap budaya Bali. Subadra (2015) berpendapat bahwa pramuwisata (tour guide) memiliki peran yang sangat signifikan dalam menginterpretasikan budaya-budaya lokal yang dikunjungi wisatawan karena pramuwisata mampu menceritakan tentang budaya yang dipersembahkan untuk pariwisata secara lengkap dan terperinci sesuai dengan kompetensi yang dimiliki oleh pramuwisata; sehingga wisatawan benarbenar mengetahui dan paham tentang budaya yang sedang dinikmati dan merasa puas dengan kegiatan wisata yang diikuti.

Sudiarta dan Subadra berpendapat bahwa kompetensi yang mencakup pengetahuan, keahlian dan prilaku mutlak harus dimiliki oleh seorang yang bekerja di sektor pariwisata, termasuk pramuwisata. Seorang pemandu wisata harus memiliki knowledge (pengetahuan) yang luas tentang budaya masyarakat lokal yang dijadikan sebagai atraksi wisata sehingga dapat memberikan edukasi kepada wisatawan yang sedang dipandu. Selain itu, pramuwisata juga harus memiliki skill (keahlian) dalam menangani wisatawan mulai dari penjemputan di Bandar udara pada saat kedatangan, selama masa tour di destinasi wisata, sampai dengan kembali ke bandar udara untuk keberangkatan. Kemampuan terakhir yang wajib dimiliki oleh pramuwisata adalah attitude (prilaku) yang mana pramuwisata harus mampu berprilaku sopan dan santun dengan menerapkan kode etik kepemanduan wisata dan bisa memberikan contoh atau teladan yang baik kepada wisatawan terutama pada saat berkunjung ke objek dan daya tarik wisata berbasis budaya yang memerlukan penghormatan terhadap nilai-nilai budaya masyarakat lokal.

Kompetensi pramuwisata dalam memberikan interpretasi terhadap suatu objek wisata budaya mempengaruhi kualitas layanan jasa kepemanduan dan kepuasan wisatawan (Lin dkk 2017). Artinya, bahwa semakin bagus kemampuan pramuwisata dalam menginterpretasikan atraksi budaya, maka semakin bagus pula kualitas pelayanan wisata yang diberikan dan semakin tinggi juga tingkat kepuasan wisatawan yang membeli dan mengikuti kegiatan wisata tersebut. Memberikan pengalaman yang berkualitas dan mengesankan dan sebaliknya, ketidakmampuan pramuwisata menginterprestasikan atraksi budaya yang dikunjungi dapat mengakibatkan terjadinya kesalahpahaman yang memicu terjadinya konflik antara wisatawan sebagai penikmat budaya dan masyarakat lokal sebagai pelaku dan pemilik budaya (Subadra, 2015).

Sebagaimana disebutkan oleh Cohen (1985), secara umum pramuwisata memiliki dua peran dalam konteks pariwisata yaitu sebagai pathfainder (pemandu arah) dan mentor (pendidik). Pramuwisata bertanggung jawab memandu dan mengarahkan wisatawan pada setiap tempat yang dikunjungi selama berada di destinasi wisata, terlebih lagi untuk objek dan daya tarik wisata berbasis warisan budaya seperti Pura Tirta Empul. Pramuwisata memiliki tantangan tersendiri ketika memandu wisatawan menikmati keindahan dan keunikan Pura ini karena di satu sisi Pramuwisata harus memberikan layanan dan 
tempat terbaik untuk bisa menikmati atraksi warisan budaya dengan nyaman dan menyenangkan; tetapi, disisi lain pramuwisata juga harus tetap menghormati aktivitas budaya Bali yang sedang berlangsung di Pura Tirta Empul dan nilainilai agama dna budaya yang dijunjung tinggi oleh umat Hindu mulai dari wisatawan menginjakkan kakinya di areal Pura, selama berlangsung kegiatan wisata di dalam areal Pura (Nista Mandala, Madya Mandala dan utama mandala), sampai dengan wisatawan meninggalkan Pura .

Dalam peranan sebagai mentor, pramuwisata harus mampu memberikan dan menambah pengetahuan wisatawan tentang Pura Tirta Empul khususnya tentang sejarah dan pentingnya Pura ini bagi masyarakat Hindu di Bali serta pemahaman tentang kegiatan-kegiatan ritual yang dilakukan oleh umat Hindu di Pura Tirta Empul. Keanekaragaman atraksi budaya yang disaksikan langsung oleh wisatawan tidak akan berarti apabila pramuwisata tidak mampu memberikan interpretasi tentang budaya tersebut. Dalam konteks ini, interpretasi merupakan proses komunikasi yang dilakukan oleh pramuwisata untuk menjembatani wisatawan dan objek serta daya tarik wisata warisan budaya yang dilihat di Pura Tirta Empul dengan memberikan penjelasan secara lengkap dan benar tentang objek-objek yang disaksikan dan kegiatan wisata budaya yang diikuti oleh wisatawan melalui proses atau kegiatan berwisata sambil belajar agar aktivitas wisatanya bermakna (Kiprutto, dkk.2012).

Kesempatan untuk menikmati dan mempelajari budaya Bali yang berbasis agama Hindu dan kawasan suci di Pura Tirta Empul tidak terlepas dari karakteristik budaya yang dinamis, yang mana budaya Bali terus dan tetap dilaksanakan oleh masyarakat lokal sebagai bagian yang tidak terlepas dari kehidupannya sehari-hari; dan selanjutnya seiring dengan berkembangnya pariwisata di Kabupaten Gianyar, maka Pura Tirta Empul juga ditetapkan sebagai objek daya tarik wisata untuk mendukung dan melengkapi objek-objek wisata lainnya yang sudah ada tanpa harus menghalangi masyarakat lokal melakukan ritual keagamaan di dalam Pura dan atau memusnahkan budaya lokal (Subadra, 2015). Selain itu, masyarakat Desa Adat Manukaya Let sebagai pengelola dan penanggung jawab Pura juga membuka diri dan memberikan kesempatan kepada wisatawan untuk masuk kedalam Pura dan menikmati atraksi budaya secara langsung dengan kompetensi membayar sejumlah uang untuk tiket masuk. Hal ini memperkuat argumentasi bahwa budaya juga memiliki karakteristik yang exchangeable atau bisa ditukarkan (Subadra, 2015: Koentjaraningrat 1996).

\subsection{Keterlibatan Masyarakat Lokal dalam Kegiatan Wisata di Pura Tirta Empul}

Masyarakat lokal Desa Adat Manukaya Let memegang peranan penting dalam perencanaan dan pengembangan wisata pusaka di Pura Tirta Empul. Pada tahap perencanaan, ikut terlibat dalam diskusi yang dipmpin oleh Ketua desa adat untuk memutuskan penetapan Pura ini sebagai salah satu objek dan daya wisata di Kabupaten Gianyar yang konsekuensinya mengijinkan wisatawan untuk masuk ke dalam areal Pura untuk menikmati keindahan arsitektur Pura dan keunikan kegiatan ritual yang diadakan di Pura. Kesepakatan dan komitmen ini sangat penting dan masih tetap dipegang teguh oleh semua anggota desa adat sehingga tidak ada silang pendapat diantara warga lokal sehubungan dengan penetapan Pura ini sebagai objek dan daya tarik wisata dan masuknya wisatawan ke dalam Pura untuk tujuan berwisata.

Pengembangan pariwisata di Pura Tirta Empul memiliki pola pengelolaan yang unik dan berbeda dengan tempat-tempat wisata berbasis warisan budaya yang ada di Bali. Hal ini merupakan contoh nyata dari pariwisata berbasis kerakyatan (communitybased tourism) di Bali yang mana semua masyarakat lokal terlibat aktif dalam kegiatan operasional. Pariwisata tidak dalam kapasitas sebagai pekerja yang dibayar (paid worker) 
karena tidak mendapatkan upah atau gaji atas pekerjaan yang dilakukan dalam operasional pariwisata. hanya bekerja dalam kapasitasnya sebagai pemelihara (pengempon) Pura yang mana bekerja atas dasar persembahan yang tulus atau sumbangan tenaga tidak berbayar (ngayah) yang merupakan bagian dari kewajiban sebagai warga Desa Adat Manukaya Let yang memiliki kewenangan untuk memelihara Pura Tirta Empul. Dengan kata lain, bekerja layaknya di perusahaan atau hotel dan industri pariwisata lainnya dan mengikuti pembagian jam dan tempat kerja yang diatur dan dibagikan oleh ketua adat sebagai pimpinan operasional wisata Pura ini, tetapi tidak mendapatkan imbalan uang atas pekerjaan yang telah dilakukan. Inilah yang membedakan keterlibatan masyarakat dan pola kerja di objek dan daya tarik wisata Pura Tirta Empul dengan objek-objek wisata lainnya di Bali yang mana bekerja mendapatkan gaji atas pekerjaan yang dilakukannya.

Di satu sisi, masyarakat lokal Desa Adat Manukaya Let yang berasal dari tiga banjar adat terlibat secara langsung dalam operasional pariwisata di Pura Tirta Empul yang dibagi dalam beberapa tugas antara lain: melakukan pengecekan tiket masuk Pura, menjaga pos sarung dan selendang dan membantu wisatawan mengenakan pakaian adat Bali tersebut, menjaga keamanan Pura, bertugas pada kotak sumbangan terletak pada halaman tersuci Pura, menjaga pos penitipan barang dan kamar mandi, serta yang tidak kalah pentingnya membersihkan areal Pura setiap hari sehingga Pura tampak bersih dan indah (Keterlibatan masyarakat ini sesuai dengan pendapat yang diungkapkan Okazaki (2008) dan Putra (2016) yang mana masyarakat lokal telah dilibatkan dalam pengembangan potensi-potensi budaya yang dimiliki. sehingga dapat dijadikan identitas budaya dan kebanggan masyarakat lokal.

Namun di sisi lain, keterlibatan masyarakat lokal dalam pariwisata di Pura ini belum dapat memberikan manfaaat ekonomi langsung kepada masyarakat karena tidak mendapatkan gaji atau dari tenaga yang telah korbankan untuk turut serta terlibat aktif dalam kegiatan wisata di tempat tersebut sebagai layaknya pekerja berbayar di industri-industri pariwisata lainnya. hanya mendapatkan kompensasi pembebasan biaya iuran rutin tahunan untuk keperluan Pujawali-upacara ritual Pura . Artinya, keterlibatan masyarakat lokal dalam kegiatan pariwisata di Pura Tirta Empul tidak memberikan manfaat ekonomi langsung kepada seluruh masyarakat lokal yang terlibat dalam operasional pariwisata untuk menopang kehidupan keluarganya karena masih tetap menjalankan profesinya masingmasing sebagai petani, peternak, pedagang dan karyawan atau pegawai lainnya untuk memenuhi kebutuhan sehari-hari; kecuali bagi yang membuka toko cindramata dan berprofesi sebagai juru foto dan pramuwisata lokal di Pura Tirta Empul yang kehidupannya sangat ketergantungan dengan kedatangan wisatawan yang datang ke Pura ini.

Pelibatan masyarakat lokal dalam operasional pariwisata di Pura Tirta Empul mengalami kendala dalam pemberian pelayanan kepada wisatawan terutama wisata asing karena tidak memiliki kompetensi (pengetahuan, keahlian dan prilaku) khusus bidang pariwisata. Dari sisi pengetahuan tentang Pura, tidak pernah diberikan pendidikan atau pelatihan khusus tentang product knowledge Pura seperti sejarah Pura, rangkaian dan makna dari ritual-ritual yang dilakukan oleh umat Hindu sehingga tidak memiliki informasi yang sama dalam memberikan penjelasan tentang Pura . Dari segi keahlian terutama penguasaan bahasa sing, sangat kurang. Dalam penyambutan wisatawan di pos sarung dan selendang misalnya, tidak semua masyarakat lokal yang sedang bertugas mampu menyapa wisatawan yang datang dan mempersilahkan untuk menggunakan sarung dan selendang.

Keterbatasan penguasaan bahasa asing merupakan salah satu penyebab tidak berjalannya proses penyapaan pada saat wisatawan datang dan juga pengucapan terima kasih dan selamat tinggal ketika wisatawan sudah selesai mengikuti kegiatan 
wisata Pura . Begitu juga dengan sopan santun dalam memerintahkan wisatawan untuk memakai sarung dan selendang, terkadang petugas penjaga hanya menggunakan bahasa tubuh dan langsung saja mengenakannya ke tubuh wisatawan tanpa terlebih dahulu menawarkan diri untuk membantu memakainya, meminta maaf atau permisi untuk mengenakannya.

Terlebih lagi, ketika ada wisatawan yang terlewatkan memakai sarung dan selendang yang sering terjadi pada saat wisatawan ramai datang secara bersamaan. Petugas jaga hanya bisa mengucapkan "halo...halo...sarung". Namun, dengan jeritan ini wisatawan juga mengerti bahwa harus kembali ke pos dan menggunakan kelengkapan untuk memasuki Pura . Suasana layanan atau service atmosphere seperti ini bisa berimplikasi pada tingkat kualitas layanan yang diberikan oleh pengelola objek dan daya tarik wisata kepada wisatawan dan juga pengalaman wisata yang dinikmati oleh wisatawan karena wisatawan merasa kurang nyaman dengan suasana seperti ini. Artinya, semakin bagus pelayanan yang diberikan oleh pengelola wisata maka akan semakin bagus dan terkesan juga pengalaman berwisatanya. Bahkan, Emir (2016) berpendapat bahwa suasana layanan merupakan salah satu faktor penentu kesetiaan pelanggan terhadap suatu produk dan layanan jasa seperti pariwisata yang juga dapat digunakan sebagai strategi untuk mendapatkan wisatawan berkunjung ulang (repeated guests) dan media promosi dan pemasaran dari mulut (word of mouth) untuk mendapatkan wisatawan baru yang mendapatkan cerita pengalaman yang menyenangkan dan mengesankan di destinasi wisata yang dikunjungi.

Selanjutnya, pada moment tertentu khususnya pada periode pelaksanaan Pujawali, masyarakat lokal tidak hanya terlibat sebagai pelaku atau personil kegiatan wisata di Pura Tirtha Empul yang melayani wisatawan yang berkunjung ke Pura, namun juga sebagai objek yang dilihat (object of the gaze) oleh wisatawan. Masyarakat lokal Desa
Adat Manukaya Let yang sedang mempersiapkan sesajen untuk ritual tahunan Pura dan yang melaksanakan serangkaian ritual keagamaan di dalam Pura merupakan objek yang sangat menarik dan autentik untuk dilihat, dinikmati dan dipelajari oleh wisatawan.

Dalam hal ini, masyarakat lokal sebagai objek yang ditonton oleh wisatawan tidak sengaja melakukan persiapan dan kegiatan ritual ini untuk kepentingan pariwisata atau dipertontonkan untuk wisatawan, tetapi melakukannya murni untuk keperluan upacara suci yang diselenggarakan di Pura secara rutin setiap tahun sebagai bagian dari tanggung jawabnya sebagai warga desa adat dilakukan dengan penuh keikhlasan dan tanpa bayaran (ngayah). Ini sesuai dengan pendapat Urry (2002) bahwa objek yang dilihat dan dinikmati oleh wisatawan di suatu destinasi pariwisata ttidak terbatas pada objek berbasis alam dan benda-benda mati, namun juga objek hidup seperti manusia dan hewan dan binatang yang dapat menambah pengetahuan dan pengalaman wisatawan.

Selain itu, masyarakat lokal juga terlibat dalam penyediaan kebutuhan wisatawan terhada souvenir yang bisa dibawa pulang ke negaranya sebagai kenang-kenangan. Sederetan took kerjajinan (artshop) yang berjajar mulai pintu ke luar objek dan daya tarik wisata Pura Tirtha Empul sampai dengan tempat parikir kendaraan dimana wisatawan naik mobil kembali untuk melanjutkan perjalanan merupakan bukti nyata bahwa masyarakat lokal Desa Manukaya Let telah terlibat dalam kegiatan pariwisata dan mendapatkan kesempatan untuk menikmati gemerlapnya pariwisata yang berkembang di daerahnya dengan cara berjualan beraneka ragam kerajinan di kawasan artshop tersebut. Hal ini sesuai dengan pendapat Zaei dan Zaei (2013) bahwa pengembangan pariwisata di suatu destinasi harus memberikan manfaat ekonomi bagi masyarakat lodal dan meningkatkan pertumbuhan ekonomi di daerah tersebut. Pemberian kesempatan bagi masyarakat lokal untuk mendapatkan keuntungan ekonomi 
(economical benefit) dari pariwisata di Pura Tirtha Empul merupakan salah satu capaian dari tujuan pengembangan pariwisata berbasis kerakyatan yang mengacu pada konsep pembangunan pariwisata berkelanjutan (sutainable tourism delevopment) yang menitik beratkan pada berkelanjutan tiga aspek yaitu ekonomi, sosial-budaya dan lingkungan (Okazaki, 2008).

\section{III.SIMPULAN}

\subsection{Kesimpulan}

Pura Tirtha Empul merupakan salah satu Pura tertua di Bali yang didirikan jauh sebelum Pura-Pura lain berdiri di seluruh wilayah Bali yang dapat dilihat secara jelas dari jenis bangunan-bangunan suci atau pelinggih yang ada di bagian paling suci Pura (utama mandala). Berdasarkan beberapa peninggalan sejarah yang ditemukan di Pura ini yang merupakan bagian terpenting dari sejarah Pura Tirtha Empul dan penyebaran agama Hindu di Bali.

Rangkaian kegiatan tour di kawasan Pura Tirtha Empul dimulai dari pembelian tiket masuk di konter yang letaknya di halaman parkir mobil dimana para wisatawan turun dari mobilnya. Kemudian wisatawan berjalan menuju ke Pura melalui pos pemeriksaan tiket dan dilanjutkan menuju konter sarung dan selendang yang letaknya sebelum gerbang masuk di halaman Nista Mandala. Semua wisatawan yang masuk ke dalam Pura Tirtha Empul wajib menggunakan sarung dan selendang yang berfungsi untuk menutupi aurat dan menghormati umat Hindu yang sedang melaksanakan kegiatan ritual di Pura .

Kompetensi pramuwisata dalam memberikan interpretasi terhadap suatu objek wisata budaya mempengaruhi kualitas layanan jasa kepemanduan dan kepuasan wisatawan. Artinya, bahwa semakin bagus kemampuan pramuwisata dalam menginterpretasikan atraksi budaya, maka semakin bagus pula kualitas pelayanan wisata yang diberikan dan semakin tinggi juga tingkat kepuasan wisatawan yang membeli dan mengikuti kegiatan wisata tersebut. Memberikan pengalaman yang berkualitas dan mengesankan dan sebaliknya, ketidakmampuan

pramuwisata menginterprestasikan atraksi budaya yang dikunjungi dapat mengakibatkan terjadinya kesalahpahaman yang memicu terjadinya konflik antara wisatawan sebagai penikmat budaya dan masyarakat lokal sebagai pelaku dan pemilik budaya.

Pengembangan pariwisata di Pura Tirta Empul memiliki pola pengelolaan yang unik dan berbeda dengan tempat-tempat wisata berbasis warisan budaya yang ada di Bali. Hal ini merupakan contoh nyata dari pariwisata berbasis kerakyatan (communitybased tourism) di Bali yang mana semua masyarakat lokal terlibat aktif dalam kegiatan operasional. Pariwisata tidak dalam kapasitas sebagai pekerja yang dibayar (paid worker) karena tidak mendapatkan upah atau gaji atas pekerjaan yang dilakukan dalam operasional pariwisata. hanya bekerja dalam kapasitasnya sebagai pemelihara (pengempon) Pura yang mana bekerja atas dasar persembahan yang tulus atau sumbangan tenaga tidak berbayar (ngayah) yang merupakan bagian dari kewajiban sebagai warga Desa Adat Manukaya Let yang memiliki kewenangan untuk memelihara Pura Tirta Empul. Dengan kata lain, bekerja layaknya di perusahaan atau hotel dan industri pariwisata lainnya dan mengikuti pembagian jam dan tempat kerja yang diatur dan dibagikan oleh ketua adat sebagai pimpinan operasional wisata Pura ini, tetapi tidak mendapatkan imbalan uang atas pekerjaan yang telah dilakukan. Inilah yang membedakan keterlibatan masyarakat dan pola kerja di objek dan daya tarik wisata Pura Tirta Empul dengan objek-objek wisata lainnya di Bali yang mana bekerja mendapatkan gaji atas pekerjaan yang dilakukannya.

\subsection{Saran}

Selama ini pengembangan pariwisata berbasis masyarakat menggunakan pendekatan community based tourism, dimana masyarakat mempunyai peran yang sangat penting dalam menunjang 
pembangunan pariwisata. Dengan demikian keterlibatan pemerintah dan swasta hanya sebatas memfasilitasi dan memotivasi masyarakat sebagai pelaku utama pengembangan desa wisata untuk dapat lebih memahami tentang fenomena alam dan budayanya, sekaligus menentukan kualitas produk wisata yang ada di desa wisatanya. Berkaitan dengan hal tersebut diatas, keterlibatan pemerintah, swasta dan masyarakat dalam pengembangan desa wisata akan membawa tuntutan bagi partisipasi masyarakat. Hal ini tentunya perlu ditumbuhkan pemahaman atau persepsi yang sama dari stakeholders terkait dan memberikan ruang yang seluas-luasnya bagi masyarakat sebagai pelaku utama pengembangan desa wisata..

\section{REFERENSI}

Abdullah, Irwan, 2006, Konstruksi dan Reproduksi Kebudayaan, Pustaka Pelajar: Yogyakarta

Agger, Ben, 2006, Teori Sosial Kritis, Kritik, Penerapan dan Implikasinya, Yogyakarta: Kreasi Wacana

Ardika, I Wayan, 1999: Pelestarian dan Pemanfaatan Tinggalan Arkeologi dalam Pengembangan Pariwisata Budaya di Bali, artikel dalam Majalah Ilmiah Pariwisata, Volume 2, Tahun 1999, Penerbit: Program Studi Pariwisata Universitas Udayana.

—, 2003, "Komponen Budaya Bali sebagai Daya Tarik Wisata". I Wayan Ardika Penyunting. Pariwisata Budaya Berkelanjutan, Refleksi dan Harapan di Tengah Perkembangan Global, Denpasar, Program Studi Magister (S2) Kajian Pariwisata Universitas Udayana. Ardika, I Gede, 2001: Pembangunan Pariwisata Bali Berkelanjutan yang Berbasis Kerakyatan, Makalah pada Seminar Nasional Bali, The Last or The Lost Paradise, di Denpasar, 1 Desember 2001.

Barker, Chris, 2005, Cultural Studies Teori dan Praktik, Yogyakarta : Bentang.
Dherana, Tjokorda Raka, 1982: Aspek Sosial Budaya dalam Kepariwisataan di Bali, Penerbit: UP. Visva Vira Denpasar.

Erawan, I Nyoman, 1999: Perimbangan Keuangan Pusat dan Daerah Untuk Mendukung Otonomi Daerah Menuju Peningkatan Kesejahteraan Rakyat, Makalah disampaikan pada Seminar Nasional " Otonomisasi daerah yang Diperluas dalam rangka Mewujudkan Pemerintah Daerah yang Mandiri”, Denpasar 9 April 1999.

Elashmawi, Farid \& Philip R. Harris, 1998: Multicultural Essential Cultural Insights For Global Business Success Management 2000, Gulf Publishing Company Houston: Texas.

Featherstone, Mike, 2001, Posmodernisme dan Budaya Konsumen, Yogyakarta: Pustaka Pelajar

Gatner, William C., 1996: Tourism Development, Principles, Processes, and Policies, an International Thomson Publishing Company: London

Giddens, Anthony, 2000, Runaway World, Bagaimana Globalisasi Merombak Kehidupan Kita, Terjemahan Andry Kristiawan $\mathrm{S}$ dan Yustina Koen S, Jakarta: Gramedia

Jenkins, Richard, 2004, Membaca Pikiran Pierre Bourdieu, Yogyakarta, Kreasi Wacana

Koentjaraningrat, 2000. Bunga Rampai Kebudayaan Mentalitet dan Pembangunan. Jakarta: PT.Gramedia.

Korn. V.E. 19323. Het Adatect van Bali. SGravenage : G. Naeff.

Kleden, Ignas, 1987, Sikap Ilmiah dan Kritik Kebudayaan, Jakarta : Gramedia

Lastra, I Made, 1997, Peraturan Kepariwisataan, Denpasar: STP Nusa Dua

Mantra, IB.1993. Bali : Masalah Sosial Budaya dan Modernisasi. Denpasar : Upada Sastra.

Pitana, I Gede 1997. Internasionalisasi Desa Adat dan Balinisasi Budaya Global.. Paper disampaikan pada Lokal Karya Internasional Pelestarian Warisan Budaya Bali. 
Piliang, Yasraf Amir, 2004, Posrealitas, Realitas Kebudayaan dalam Era Posmetafisika, Yogyakarta,: Jalasutra.

Pitana, I Gde, 1994, Editor: Dinamika Masyarakat dan Kebudayaan Bali, Denpasar: BP 2000: Cultural Tourism In Bali, A Critical Appreciation, Denpasr: Universitas Udayana Denpasar.

Pitana, I Gde dan Gayatri, Putu.G, 2005, Sosiologi Pariwisata, Yogyakarta: ANDI

Ratna Kutha, 2006, Teori, Metode, dan Teknik Penelitian Sastra, Yogyakarta: Pustaka Pelajar

Richards, Greg and Derek Hall, 2002, Tourism and Sustainable Community Development, London: Routledge.

Swarsi, Geriya dan I Wayan Geriya, 2003, "Nilai Dasar dan Nilai Instrumental dalam Keragaman Kearifan Lokal Daerah Bali", makalah Dialog Budaya, Denpasar: Proyek Pemanfaatan Kebudayaan Daerah Bali.

Sirtha, I Nyoman, 2001, Pariwisata dalam kaitannya dengan Sosiokultural Masyarakat Bali, makalah disampaikan pada matrikulasi Program Studi Magister Kajian Pariwisata Unud, Tahun 2001/2002, tanggal 11 Agustus 2001. 